\title{
A teologia da cruz em Jon Sobrino O caminho mistagógico da kénosis
}

\author{
Orientador: Paulo Cezar Costa \\ Mestrando: Sueli da Cruz Pereira \\ Área de Concentração: Teologia Sistemático-Pastoral \\ Linha de Pesquisa: Fé e Teologia
}

A reflexão cristológica nos últimos anos tem procurado responder as questões sobre Jesus Cristo trazidas ao longo dos séculos pela Igreja através do Novo Testamento e dos dogmas cristológicos. Uma dessas questões é o significado da cruz de Jesus. Na América Latina foram desenvolvidas várias reflexões a partir do seu "próprio poço" partindo do Jesus histórico. Dentre elas destaca-se a do teólogo Jon Sobrino. Sua reflexão é uma proposta de condução ao sentido original da cruz a partir de nossa realidade ainda marcada por tanto sofrimento humano e onde os crucificados são uma grande maioria. Nossa dissertação busca apresentar possíveis consequências para todos as pessoas, principalmente para os seguidores de Jesus Cristo, para se vivenciar uma prática mais humana e humanizadora quando o ponto de partida é a compreensão da cruz proposta por Sobrino.

Palavras-chave: Teologia da Cruz; Jon Sobrino; Cruz. 